\title{
Non-smoking policies and practices in Norwegian delivery units in 1994
}

\begin{abstract}
Objective-To determine the number of delivery units in Norway that have become smoke free for employees and patients. Design-A pre-categorised questionnaire was sent in September 1994 to the physician or midwife responsible for each of the 68 delivery units in the country.

Main outcome measures-Hospital smoking policies, reported difficulties in implementation, use of nicotine replacement therapy in patients, and provision of information on tobacco-related health hazards to patients.

Results-Fifty-six units (82.3\%), accounting for $\mathbf{9 3 \%}$ of all deliveries in Norway in 1993 , responded. Of these, $42(75 \%)$ were smoke-free for employees, and $33(59 \%)$ for patients. Nearly all had become smoke-free after 1990. No significant difference was seen according to type or size of delivery unit. No difficulties in the implementation of policies restricting smoking were reported. Thirty-one (55\%) routinely informed patients of the health implications of smoking during pregnancy. Two units offered nicotine replacement therapy to patients.

Conclusion-Most Norwegian delivery units were smoke-free for both employees and patients. Provided that the recent trend toward adoption of smoke-free policies continues, all delivery units in Norway should be smoke-free by 19971998.
\end{abstract}

(Tobacco Control 1996;5:139-141)

Keywords: Norway; delivery units; smoking policy

\section{Introduction}

An increasing number of publications regarding the deleterious effects of smoking during pregnancy have appeared during the last few decades. Despite this knowledge, about $35 \%$ of pregnant women in Norway are daily smokers. ${ }^{1}$ There seems to be agreement that in the developed world, smoking is the most important preventable cause of poor pregnancy outcome. Intervention studies are numerous but little has been published regarding how the problem is handled in hospitals caring for complicated pregnancies. However, in some countries, such as the US and the UK, smoke-free hospital environments for both employees and patients has been enforced during the last decade. ${ }^{2}$

In August 1991, the Norwegian Ministry of Health and Social Affairs distributed its Action plan for smoke-free health institutions. ${ }^{3}$ The goal of this plan was that all health institutions in Norway would have established a smoke-free environment for all employees before 1 January 1994. A study performed in $1993^{4}$ evaluated the progress toward establishing smoke-free health institutions. Three types of institutions were included in the study: hospitals, institutions for the elderly, and psychiatric institutions. About $70 \%$ of the hospitals and about $50 \%$ of the institutions for the elderly and psychiatric institutions had decided to establish smoke-free environments for their employees. About two-thirds of the institutions without such a policy did not have any plans to develop one. It was clear that further action was needed to establish smoke-free health institutions in all of Norway.

In January 1995, Action plan for smoke-free health institutions: patients was published. The action plan was distributed to all Norwegian hospitals, and recommended a stepwise implementation of smoke-free environments for patients. The plan emphasised the importance of smoke-free environments in units and departments with patients for whom the benefits of not smoking is most pronouncedfor example, delivery units and departments with patients with lung and heart diseases. The aim of our study was to determine the degree to which delivery units in Norway have become smoke-free for employees and patients, and to elucidate the problems in achieving smoke-free units.

\section{Methods}

In Norway all delivery units are public, and a complete list of these units, including information on size and number of deliveries per year, was available from the Norwegian Ministry of Health and Social Affairs. In September 1994, a questionnaire was sent to all 68 registered delivery units on this list for completion by the physician or midwife responsible for administration. The questionnaire consisted of 14 pre-categorised questions, concerning overall hospital smoking policy, administrative background information about the unit, smoking policy for employees and patients, and information provided to patients on the health consequences of smoking for puerperal women and their offspring.

After one mailing, responses were received from $56(82.3 \%)$ of the departments, and no additional attempts were made to obtain a higher response rate. Responding units accounted for about 56000 (93\%) of all 60086 deliveries in Norway in 1993. The number of deliveries in each unit averaged

\author{
Correspondence to: Prof. \\ Department of Obstetric \\ and Gynecology, 5021 \\ Haukeland Hospital, Bergen \\ Norway. \\ Norwegian Cancer \\ Oslo, Norway \\ A Hafstad

Department of
Obstetrics and
Gynecology,
Haukeland Hospital,
University of Bergen,
Bergen, Norway
O-E Iversen
Norwegian Cancer
Registry, Montebello,
Oslo, Norway
A Hafstad
Correspondence to: Prof.
Ole-Erik Iversen,
Department of Obstetrics
and Gynecology, 5021
Haukeland Hospital, Bergen,
Norway.


1000 (range $2000-5000)$. Forty (71\%) had an obstetrician on call, but only $16(29 \%)$ always had an obstetrician in the hospital.

\section{Results}

Forty-two $(75 \%)$ of the 56 units had a total ban on indoor smoking for all employees (table 1). For all unit sizes except the smallest units (fewer than 100 deliveries a year), most departments had smoke-free environments. Seven hospitals had decided to provide a smoke-free environment for employees but had not yet implemented the policy, leaving only seven $(11 \%)$ of the respondents without a nonsmoking environment either planned or in place.

Regarding the policy for patients, 33 units (59\%) had decided to become non-smoking whereas $23(41 \%)$ had not (table 2$)$. When the data were stratified according to the number of deliveries in each unit, no clear pattern emerged. Half (3/6) of the university hospitals (table 3) and most (5/8) of the smallest units (table 2) still allowed smoking. None of the hospitals without a ban on smoking permitted smoking in patient rooms or in restrooms, but only in separate smoking rooms or verandas, etc. When asked whether the implementation of non-smoking policies for patients had raised particular difficulties, none of the hospitals reported problems.

The first non-smoking unit prohibited smoking for pregnant and puerperal women in 1980 , but momentum toward the adoption of such policies occurred only after 1990 (figure). Two units offered nicotine replacement therapy (patch or gum) to patients. In six (11\%) of the hospitals without a smoking ban, the nursing staff offered transport of the bedridden to smoking rooms.

Regarding the provision of information on the health hazards of smoking during pregnancy to both mother and child, 31 units $(55 \%)$ routinely informed hospitalised women of these hazards, and no difference in this finding was seen between units with or without a smoking ban. Nineteen departments (34\%) routinely provided information on the impact of passive smoking on infants, and the remaining departments provided this information on a more casual basis.

\section{Discussion}

The main finding of this study is that most Norwegian delivery units and hospitals have already introduced a total ban on smoking indoors for both employees and pregnant women, increasingly so after 1990. It may be of some surprise that these policies have been implemented, according to the hospitals'

Table 1 Distribution of Norwegian delivery units by number of births per year and smoking policy for employees

\begin{tabular}{llllll}
\hline & $<100$ & $100-499$ & $500-999 \geq 1000$ & $\begin{array}{l}\text { Total } \\
(\%)\end{array}$ \\
\hline $\begin{array}{l}\text { Smoke-free } \\
\begin{array}{l}\text { Smoking } \\
\text { allowed }\end{array}\end{array}$ & 4 & 12 & 9 & 17 & $42(75)$ \\
\begin{tabular}{l} 
Total \\
\hline
\end{tabular} & 8 & 17 & 11 & 20 & 56 \\
\hline
\end{tabular}

Table 2 Distribution of Norwegian delivery units by number of births per year and smoking policy for patients

\begin{tabular}{llrrrl}
\hline & $<100$ & $100-499$ & $500-999 \geq 1000$ & $\begin{array}{l}\text { Total } \\
(\%)\end{array}$ \\
\hline $\begin{array}{l}\text { Smoke-free } \\
\begin{array}{l}\text { Smoking } \\
\text { allowed }\end{array}\end{array}$ & 5 & 11 & 5 & 14 & $33(59)$ \\
Total & 8 & 17 & 11 & 20 & 56 \\
\hline
\end{tabular}

Table 3 Distribution of Norwegian delivery units by type of hospital and smoking policy for patients

\begin{tabular}{|c|c|c|c|c|c|}
\hline & University & Central & County & Cottage & $\begin{array}{l}\text { Total } \\
(\%)\end{array}$ \\
\hline Smoke-free & 4 & 18 & 8 & 3 & $33(59)$ \\
\hline $\begin{array}{l}\text { Smoking } \\
\text { allowed }\end{array}$ & 6 & 12 & 2 & 3 & $23(41)$ \\
\hline Total & 10 & 30 & 10 & 6 & 56 \\
\hline
\end{tabular}

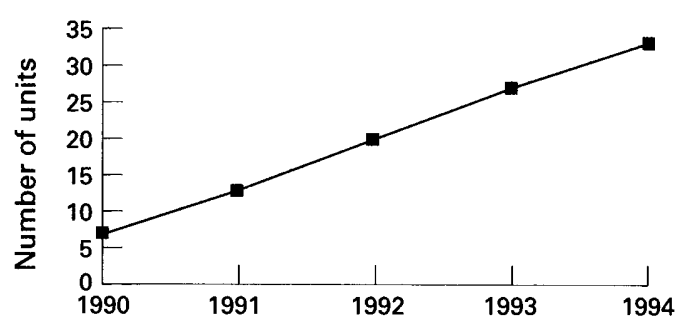

The cumulative number of delivery units in Norway with a total ban on smoking for pregnant and puerperal women, $1990-1994($ total $=33 / 56)$.

reports, without major problems. However, these reports are consistent with the findings of previous research on smoke-free environments in Norwegian hospitals. ${ }^{4}$

There may be a gap between policy adoption and implementation. A limitation of our study is that we have no direct documentation of compliance with the policies that have been adopted. Thus some smoking may continue to occur in delivery units despite rules and regulations proscribing it. However no indications of widespread non-compliance have come to our attention, and we believe smoke-free policies for employees and patients are followed consistently.

An important aim for both the present and the future must be to reduce smoking in pregnancy to a minimum. In that context, the reduction of smoking for the limited time in hospital may seem insignificant. On the other hand, considering the abundant evidence of the dangers of smoking during pregnancy, and the growing evidence that workplace smoking bans reduce the prevalence of smokers, ${ }^{5-9}$ smoke-free delivery units may be a valuable contribution. At the Johns Hopkins Medical Institutions smoking prevalence among all groups of employees declined by an average of $25 \%$ six months after enforcement of a smokefree environment for the workplace. ${ }^{7}$ One might also assume that employees in delivery units are seen as role models for pregnant and puerperal women.

The use of nicotine replacement therapy in two units is worth noting. Although considered contraindicated in pregnancy by Norwegian health authorities and the manufacturer, nicotine replacement therapy was considered by the 
obstetricians to be less harmful to the fetus than smoking, consistent with the views of Benowitz. ${ }^{10}$

Provided that the rate of delivery units becoming non-smoking in the years to come will equal that of the past three years, all Norwegian delivery units should be smoke-free for both patients and employees by 1997-1998. This accomplishment will contribute to the Norwegian Medical Association's goal that the country as a whole be smoke-free by the year 2000 .

1 Peen A, Bergsjø P, Nesheim BI, Ullern $\AA$ M, Hegglund BM, Matheson I. En karakteristikk av to norske fødepopulasjoner I Akershus og Hordaland fylker (In Norwegian). Tidskr Nor Lageforen 1991;111:1613-16.

2 Longo DR, Brownson RC, Kruse RL. Smoking bans in US hospitals: results of a national survey. $\mathscr{f} A M A$ 1995; 274:488-91.

3 Norsk Sykepleierforbund, Norsk Hjelpepleierforbund, Den Norske Lægeforening, Kommunenes Sentralforbund,
Helsetjenestens Administrasjonforbund, og Sosialdepartementets arbeidsgruppe for røykfritt Norge år 2000 Handlingsplan for roykfrie helseinstitusjoner, Oslo. Oslo, 1991.

4 Hafstad A, Kjærheim K, Sanner T. Smoke-free health institutions in Norway (In Norwegian) Tidskr Nor Lageforen 1994;114:52-6.

5 Biener L, Abarns D, Follick M, Dean LA. A comparative evaluation of a restrictive smoking policy in general hospievaluation of a restrictive smoking policy

6 Gottlieb N, Eriksen M, Lovato C, Weinstein R, Green L. Impact of restrictive work site smoking policy on smoking behavior, attitudes and norms. F Occup Med 1990;32:1623.

7 Stillman FA, Becker DM, Swank RT, et al. Ending smoking at The Johns Hopkins Medical Institutions. An evaluation of smoking prevalence and indoor pollution. $\mathscr{f} A M A 1990$; 264:1565-9

8 Joseph AM, Knoop JM, Nichol KL, Pirie PL. Determinants of compliance with a national smoke-free hospital standard. $\mathcal{F} A M A$ 1995;274:491-4.

9 Longo DR, Brownson RC, Johnson JC, et al. Hospital smoking bans and employee smoking behavior: Results of a national survey. $\mathcal{F} A M A$ 1996;275:1252-7.

10 Benowitz NL. Nicotine replacement therapy during pregnancy. $\mathcal{F} A M A$ 1991;266:3174-7.

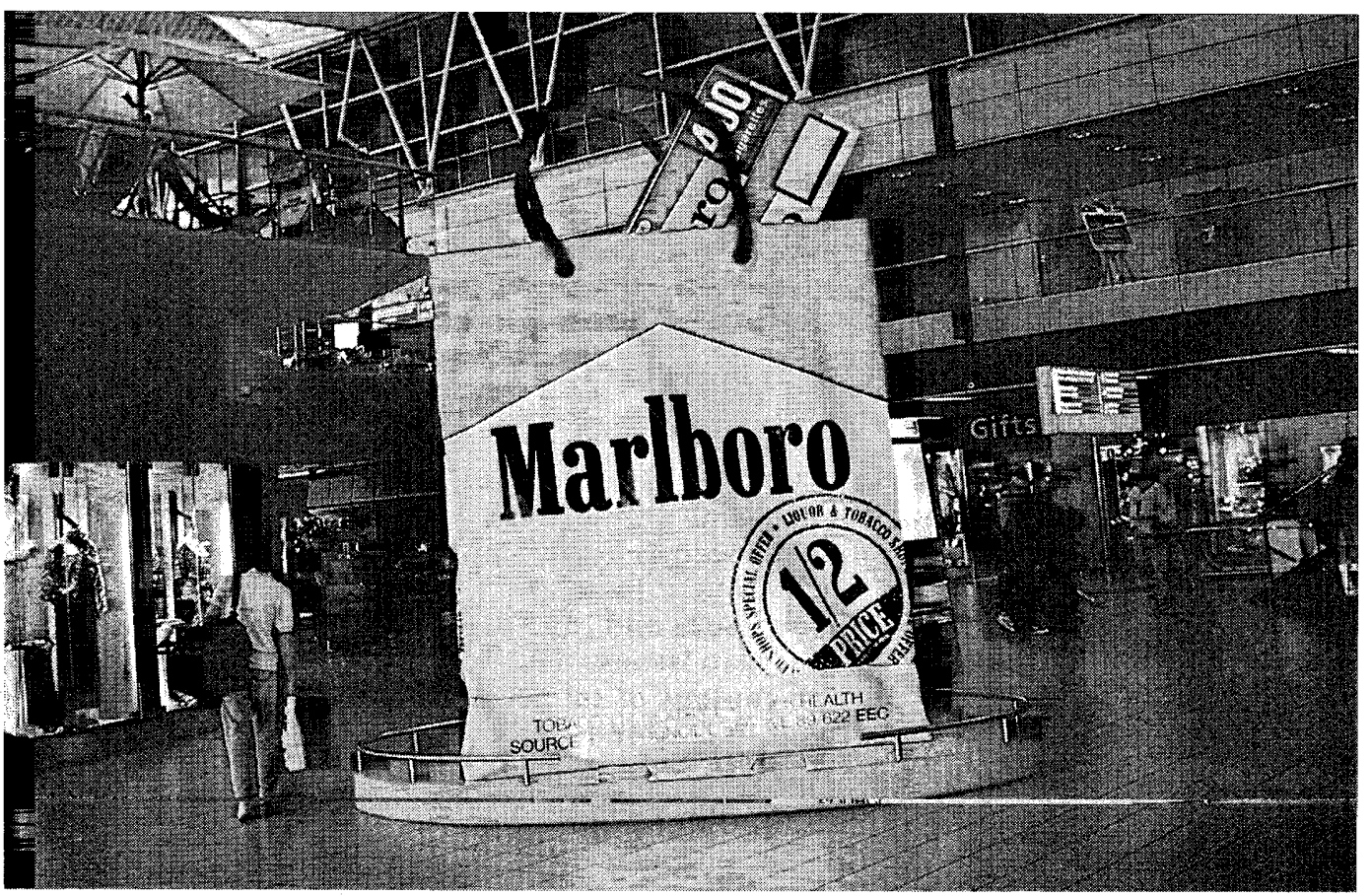

Amersterdam Airport, fuly 1996. Submitted by fohn slade 